\title{
Marta Makuch Gerontechnologia - rozważania o rozwoju technologii i techniki w kontekście poprawy jakości życia osób starszych
}

Gerontechnology: reflections on technological and technical developments to enhance the quality of elderly people's lives

This article reflects on technical and technological progress in light of society aging and on its impact on the society and economy, as well as on the states' socio-economic development from the perspective of social science. The author also discusses the complex effects of population aging and describes the last stage of human life. The elderly face numerous limitations (especially health problems) and modern technology can provide appropriate solutions. Gerontechnology is the answer of modern science to the needs of the social class in question. The article provides examples of enhancing the quality and comfort of elderly people's lives with the use of innovative products and services.

\begin{tabular}{r|l}
\hline DOI & https://doi.org/10.31268/StudiaBAS.2020.23 \\
\hline Słowa kluczowe & gerontechnologia, technika, rozwój, starzenie się, jakość życia, zdrowie \\
\hline Keywords & gerontechnology, technics, development, aging, quality of life, health \\
\hline 0 autorce & $\begin{array}{l}\text { doktor hab., Instytut Politologii, Uniwersytet Wrocławski • } \\
凶 \text { marta.makuch@uwr.edu.pl ・ ORCID 0000-0002-7370-1743 }\end{array}$ \\
\hline
\end{tabular}

\section{Wstęp}

Rozwój społeczeństw - w szczególności obecnie, w XXI w. - jest ściśle związany z postępem techniki i technologii. Oczywiście jest on różny, tak jak są odmienne czynniki rozwoju w poszczególnych państwach oraz jego poziom. Występują bowiem w dalszym ciągu znaczne dysproporcje, które nie ulegają zmianie. Takie wskaźniki, jak choćby indeks jakości życia publikowany corocznie przez Organizację Narodów Zjednoczonych w Raporcie o rozwoju społecznym (Human Development Raport) - HDI (Human Development Index), obrazują ten fakt ${ }^{1}$.

Innym elementem, który bierze się aktualnie pod uwagę przy badaniu rozwoju społeczno-gospodarczego oraz postępu naukowo-technicznego państw, jest także poziom ich innowacyjności. Od niego uzależnia się bowiem konkurencyjność gospodarki, a w dalszej perspektywie właśnie możliwość rozwoju oraz poprawy jakości życia².

Wobec tego swoistym motorem społeczeństwa, gospodarki czy państwa jest postęp, w tym ten, który ma miejsce w technologii i technice. A on z kolei zależy od zaawansowania rozwoju

1 United Nations Development Programme, Human Development Reports, table 2: Human Development Index trends, 1990-2018, http://hdr.undp.org/en/content/table-2-human-development-index-trends-1990\%E2\%80\%932018 [dostęp: 2 czerwca 2020 r.].

2 A. Migała-Warchoł, M. Sobolewski, Innowacyjność gospodarki a poziom życia mieszkańców państw Unii Europejskiej, „Barometr Regionalny” 2017, t. 15, nr 4, s. 44, http://br.wszia.edu.pl/zeszyty/pdfs/br50_05migala. pdf [dostęp: 2 czerwca 2020 r.]. 
tych właśnie trzech elementów (czyli społeczeństwa, gospodarki i państwa). Stąd mamy do czynienia ze swego rodzaju sprzężeniem zwrotnym.

Nikt nie kwestionuje obecnie faktu, że technologia (a przede wszystkim technika) powinna służyć człowiekowi. To dzięki niej można podnosić komfort życia osób, które jeszcze niedawno miały ograniczone możliwości funkcjonowania i nierzadko były wykluczane z powodu np. choroby czy niepełnosprawności, pojawiającej się często wraz z sędziwym wiekiem.

W artykule, który traktuje o wspomnianych kwestiach - o rozwoju i o postępie technicznym skoncentrowano się na narastających wielowymiarowych skutkach starzenia się populacji. W tym kontekście zaprezentowano wybrane przykłady, jak dzięki współczesnym wynalazkom i projektom naukowców i inżynierów można poprawić jakość życia osób ze starszych grup wiekowych. Celem opracowania jest także odpowiedź na pytanie: w jaki sposób nowe środki techniki oraz jak rozwój technologii zmieniają styl oraz komfort życia osób starszych? Pomocne w realizacji celu będzie sięgnięcie do dorobku dość nowej, interdyscyplinarnej nauki - gerontechnologii. Opracowanie zostało przygotowane na podstawie analizy piśmiennictwa (zwłaszcza czasopism polskich i zagranicznych), raportów oraz danych dostępnych głównie w elektronicznych zasobach instytucji statystycznych oraz organizacji międzynarodowych.

\section{Istota technologii i rozwoju techniki dla społeczeństwa, państwa i gospodarki - zarys z perspektywy nauk społecznych}

Definicja słowa „technologia” i jego znaczenie są różne w literaturze. W jednych źródłach czytamy, że jest to dostęp do najnowocześniejszego sprzętu i aplikacji teleinformatycznych, w innych - sposób wykonywania określonych czynności, a w jeszcze innych - zaawansowane i skomplikowane metody produkcyjne, opracowywane i wykorzystywane przez wysoko wyspecjalizowane przedsiębiorstwa. Technologia dotyczy działań wykorzystujących osiągnięcia techniki. Warto wspomnieć, że powszechnie te słowa używa się zamiennie (mimo podkreślania wyraźnych, pierwotnych różnic w ich znaczeniu przez ekspertów) ${ }^{3}$.

Pojęcie „technologia” wywodzi się z języka greckiego i stanowi połączenie dwóch słów: téchnē (sztuka, rzemiosło) oraz lógos (słowo, nauka). Z inżynierskiego punktu widzenia technologia jest procesem wytwarzania konkretnego wyrobu. W podejściu ekonomicznym wskazuje się natomiast na zespół wszystkich technik produkcji lub metod wytwarzania, które są dostępne w danym przedsiębiorstwie ${ }^{4}$. Przedsiębiorstwa poszukują możliwości doskonalenia istniejących technologii oraz pozyskiwania nowych, stwarzających dalsze możliwości. Wprowadzenie takich zmian w technologii, nowych dla przedsiębiorstwa, jest przykładem innowacji

3 O różnicy między pojęciami „technologia” a „technika” zob. m.in.: Z. Łucki, Proszę... nie mówmy "technologia" na technike!, https://www.uci.agh.edu.pl/bip/63/11_63.htm [dostęp: 2 czerwca 2020 r.]; R. Sobczak, Inżynier: wiedza, technika, technologia, „Zeszyty Naukowe Wydziału Elektrotechniki i Automatyki Politechniki Gdańskiej" 2017, t. 52, s. 116. Z uwagi na powszechne zamienne stosowanie tych słów w języku polskim w niniejszym tekście podobnie przyjęto tłumaczenie słowa technology jako „technologia” - gerontechnology.

4 S. Gomułka, Teoria innowacji i wzrostu gospodarczego, Centrum Analiz Społeczno-Ekonomicznych, Warszawa 1998, s. 24. 
(technologicznej) $^{5}$. Zmiany te bazują najczęściej na kreatywności, różnorodności, akceptacji eksperymentowania oraz możliwości popełniania błędów w warunkach kontrolowanych.

W literaturze przedmiotu traktuje się też technologię jako zjawisko społeczno-technologiczne, daleko wykraczające poza określone systemy zarządzania, posiadane umiejętności czy wykorzystywane maszyny i urządzenia. W szerokim kontekście obejmuje więc procesy społeczne, psychologiczne i kulturowe, które z odpowiednim wsparciem systemów zarządzania stanowią istotny czynnik w procesie transferu technologii. To także, co podkreślają badacze, połączenie wiedzy i doświadczenia, które może być siłą napędową do tworzenia nowych i rozwoju istniejących technologii. Współpraca pomiędzy nauką a przemysłem może przynieść praktyczne zastosowania innowacyjnych rozwiązań technologicznych, których wdrożenie zapewni organizacji przewagę konkurencyjną na rynku, a także będzie źródłem inspiracji dla innych rozwiązań. Nieodłącznie wiąże się z tym ocena kosztów ich wdrożenia i stosowania. Postęp technologiczny i techniczny zatem jest traktowany jako siła sprawcza przemian w innych wymiarach, przede wszystkim społecznym i ekonomicznym.

\section{Technologia i technika w XXI w. - w dobie starzejącego się społeczeństwa}

Technika jest nieodzownym elementem każdej sfery naszego życia. To, czy jej wpływ jest pozytywny czy negatywny, pozostaje dla wielu kwestią dyskusyjną. Podobnie jest z podejściem do postępu technicznego. Gdy jednak mówi się o rozwoju nauki, rozwoju techniki, postępie technicznym czy postępie cywilizacyjnym, to już niemal z założenia mówi się o czymś korzystnym, czymś dobrym. Dzieje się tak ze względu na to, że terminy: „rozwój”, „rozwinięty”, „progres”, „postęp”, wnoszą pozytywny ładunek emocjonalny, ponieważ oznaczają jakiś dodatek do czegoś, co już istnieje. Toteż sformułowanie „postęp techniczny” informuje o czymś - wydawałoby się - dobrym, pożytecznym. „Oznacza rozwój, który dokonuje się w dziedzinie techniki, czyli przyrost wiedzy dotyczącej tego, jak tworzyć nowsze, lepsze, wydajniejsze, efektywniejsze artefakty; zwiększenie możliwości, zdolności i umiejętności produkowania wytworów technicznych; wzrost liczby artefaktów, które nasycają życie codzienne człowieka"6 ${ }^{\prime 6}$ W negatywnym podejściu technika traktowana jest jako coś, co stanowi zagrożenie dla człowieka. Te nastawienia przejawiają się w ramach niektórych ruchów społecznych ${ }^{7}$. W tym opracowaniu jednak akcent zostanie położony na pozytywne skutki niesione nie tylko przez samą technikę, lecz także przez innowacyjne rozwiązania wykorzystywane przez coraz większą grupę osób starszych. Jest to związane z demograficznym procesem tzw. starzenia się ludności. Trzeba bowiem podkreślić, że demografia to jeden z tych czynników, które eksperci zaliczają do tzw. megatrendów mających wpływ na rozwój całego świata do 2050 r. ${ }^{8}$

5 Ibidem, s. 8.

6 T. Łach, Strach przed postępem - kilka uwag o nurtach antytechnicznych, „Kultura i Wartości” 2012, nr 4, s. 35-36, http://kulturaiwartosci.umcs.lublin.pl/wp-content/uploads/2011/11/Tomasz-\%C5\%81ach-Strach-przed-post\%C4\%99pem-kilka-uwag-o-nurtach-antytechnicznych.pdf [dostęp: 2 czerwca 2020 r.].

7 Ibidem, s. 33.

8 K. Prandecki, Rola megatrendów w przewidywaniu przyszłości, „Przyszłość. Świat - Europa - Polska” 2012, nr 2, s. 75-94; Megatrends 2015. Making sense of a world in motion, EY, 2015, https://www.ey.com/Publication/ 
Czym jest starzenie się? Starzenie się to proces, a starość to stan, na które należy patrzeć z perspektywy jednostki. Starzenie się jest przecież procesem naturalnym, a w przypadku człowieka - bardzo indywidualnym i zależnym od wielorakich czynników. Ale też żaden człowiek nie starzeje się w całkowitej izolacji od innych. Proces starzenia się jednostki jest wpisany zarówno w zachodzące zmiany społeczno-gospodarcze i kulturowe, jak i w szerszy proces starzenia się innych ludzi, który przybrał w ostatnich dekadach formę starzenia się ludności (siwienia, srebrzenia). Społeczny wymiar starzenia się człowieka wymaga poszerzania problematyki rozważań o aspekty nie tylko prawne, medyczne i ekonomiczne, lecz także psychologiczne czy etyczne (aksjologiczne) ${ }^{9}$.

Proces starzenia się nie jest równomierny we wszystkich regionach świata. Aby ustalić, w której fazie demograficznej znajduje się dane społeczeństwo, do obliczeń wprowadza się proporcje, określane jako tzw. stopa bądź iloraz starości. Pojęcia te, wyrażane w procentach, rozumiane są jako:

- udział w populacji generalnej osób w wieku 60 lat i więcej - miara WHO ${ }^{10}$;

- udział w populacji generalnej osób w wieku 65 lat i więcej - miara ONZ (Eurostat) ${ }^{11}$;

- udział w populacji generalnej osób w wieku emerytalnym (poprodukcyjnym) ${ }^{12}$ - skala GUS ${ }^{13}$. Do najważniejszych przyczyn wzrostu odsetka osób starych w społeczeństwie należą przede wszystkim wydłużanie czasu trwania ludzkiego życia oraz spadek liczby urodzeń. Ten pierwszy czynnik wpływa ponadto na bezwzględny wzrost liczby ludzi starych. Proces demograficznego starzenia się społeczeństwa charakteryzuje się ważnymi cechami, takimi jak: feminizacja, singularyzacja czy podwójne starzenie $\operatorname{się}^{14}$. Jakie są przewidywane efekty powyższych trendów, które będą - jak się zdaje - postępować, a z czasem pogłębiać? Czy opisane procesy demograficzne wiążą się wyłącznie z problemami i skutkami negatywnymi?

vwLUAssets/ey-megatrends-report-2015/\$FILE/ey-megatrends-report-2015.pdf [dostęp: 2 czerwca 2020 r.]; What's after what's next? The upside of disruption. Megatrends shaping 2018 and beyond, EY, 2018, https:// assets.ey.com/content/dam/ey-sites/ey-com/en_gl/topics/disruption/ey-megatrends-final-onscreen.pdf [dostęp: 2 czerwca 2020 r.].

9 Indywidualne aspekty starzenia się. Między możliwościami a ograniczeniami, red. A. Stogowski, S. Dzięgielewska-Gęsiak, Wyższa Szkoła Nauk Humanistycznych i Dziennikarstwa w Poznaniu, Poznań 2013, s. 7-8.

10 Według tej organizacji do 2050 r. w stosunku do 2015 r. odsetek osób powyżej 60. roku życia zwiększy się na świecie z 12\% do 22\%; World Health Organization, Ageing and health, https://www.who.int/news-room/ fact-sheets/detail/ageing-and-health [dostęp: 2 czerwca 2020 r.].

11 Zgodnie z prognozami ONZ mediana wieku jako inny wskaźnik starzenia się społeczeństwa w 2050 r. wyniesie 36,1 (w stosunku do 23,5 w 1950 r. i 29,6 w 2015 r.). Wśród 10 państw wymienionych jako "najstarsze" znajduje się Polska; United Nations, World Population Prospects. The 2015 Revision. Key Findings and Advance Tables, New York 2015, s. 32, https://population.un.org/wpp/Publications/Files/Key_Findings_WPP_2015. pdf [dostęp: 2 czerwca 2020 r.].

12 Według ekonomicznych grup wieku. Zob. Główny Urząd Statystyczny, Sytuacja demograficzna osób starszych i konsekwencje starzenia się ludności Polski w świetle prognozy na lata 2014-2050, Warszawa 2014, s. 39-42.

13 Z. Szarota, Społeczno-demograficzne aspekty starzenia się społeczeństwa [w:] R.J. Kijak, Z. Szarota, Starość. Między diagnozq a działaniem, Centrum Rozwoju Zasobów Ludzkich, Warszawa 2013, s. 7.

14 P. Błędowski, B. Szatur-Jaworska, Z. Szweda-Lewandowska, P. Kubicki, Raport na temat sytuacji osób starszych w Polsce, Instytut Pracy i Spraw Socjalnych, Warszawa 2012, s. 5-6. 
Od początków badań nad konsekwencjami procesu starzenia się ludności naukowcy postrzegali wzrost udziału osób starszych w społeczeństwie jako zjawisko niepokojące. To jednostronne w zasadzie podejście - nazwane np. przez Ellen M. Gee „demografią apokaliptyczną"15 opierało się na takich założeniach, jak: homogenizacja zbiorowości seniorów, „obwinianie” osób starszych, postrzeganie procesu starzenia się w kategoriach problemu społecznego, czy na rozbudzaniu konfliktów międzypokoleniowych na bazie dyskusji o międzypokoleniowej (nie)sprawiedliwości i (nie)równości ${ }^{16}$.

Z pewnością konsekwencje tego procesu są wielopłaszczyznowe i przybierają różny wymiar. Można wśród nich wymienić konsekwencje ekonomiczne (gospodarcze), społeczno-kulturowe czy polityczne. Piotr Szukalski podkreśla, że te skutki będą widoczne zwłaszcza w sferze „opieki zdrowotnej, relacji międzypokoleniowych w społeczeństwie i rodzinie" ${ }^{\prime 17}$. Natomiast wspomniane wyżej założenia demografii apokaliptycznej podlegają obecnie zmianom. W ostatnich dekadach mamy bowiem do czynienia z wyraźnym przeformułowaniem owych warunków. Najważniejsze zmiany, jakie zachodzą, odnoszą się do stałej poprawy stanu zdrowia seniorów, wzrostu świadomości swych praw wśród osób starszych i zainteresowania koncepcją pomyślnego starzenia się.

Podsumowując ten wątek: ta wielowymiarowa wiedza o starzeniu się prowadzi do wniosku, że obecnie stanowi ono jeden z ważnych aspektów wpływających na kondycję demograficzną świata. Liczba ludności wzrasta, dlatego że wydłuża się wiek (przedłużenie życia zwłaszcza w zdrowiu ma miejsce dzięki warunkom socjalnym oraz zdobyczom medycyny). Struktura zmienia się jednak nie tylko w skali świata (wyższy przyrost w krajach uboższych), lecz także wewnątrz państw - kraje rozwinięte coraz częściej stają przed wyzwaniami wynikającymi z efektu starzenia się społeczeństwa, co wymusza zmiany w podejściu do polityki wobec osób starszych (ale i wobec starzenia się) oraz motywuje do pracy nad innowacyjnymi rozwiązaniami mogącymi polepszyć jakość życia tej grupy osób ${ }^{18}$.

\section{Wyzwania ostatniego okresu życia - etap starości i starości starczej}

Starzenie się, jak wspomniano, posiada wymiar osobisty. Ten etap w życiu wiąże się ze zmianami, które zachodzą z różnym nasileniem, ale nieuchronnie i nieodwracalnie. Przebiega on w sferze biologicznej, psychologicznej i społecznej człowieka, a zmiany w obrębie jednej ze

15 E.M. Gee, Population and Politics: Voodoo Demography, Population Aging, and Social Policy [w:] The Overselling of Population Aging: Apocalyptic Demography, Intergenerational Challenges, and Social Policy, red. E.M. Gee, G.M. Gutman, Oxford University Press, Toronto, Ontario 2000, s. 5-25.

16 P. Szukalski, Zagrożenie czy wyzwanie - proces starzenia się ludności, „Polityka Społeczna” 2006, nr 9, s. 6.

17 P. Szukalski, Proces starzenia się ludności - przyczyny, etapy, konsekwencje [w:] Geriatria z elementami gerontologii ogólnej. Podręcznik dla lekarzy istudentów, red. T. Grodzicki, J. Kocemba, A. Skalska, Via Medica, Gdańsk 2006, s. 16.

18 O ile polityka wobec ludzi starych ma charakter krótkookresowy, o tyle cele polityki wobec starości wiążą się z działaniami długookresowymi, których efekty mogą być zauważalne dopiero po upływie wielu lat. Ponadto adresatami polityki społecznej wobec starości są nie tylko ludzie starzy. Takie podejście i taki podział stosuje się od dawna w państwach europejskich, w których proces starzenia się rozpoczął się znacznie wcześniej niż w Polsce. M. Makuch, Polityka społeczna dotycząca starości [w:] K. Zamorska, M. Makuch, Starzenie się społeczeństwa. Wymiar społeczny, gospodarczy i polityczny, Księgarnia Akademicka, Kraków 2018, s. 95-134. 
sfer wpływają na funkcjonowanie w pozostałych, wszystkie bowiem się przenikają i warunkują. „Związek składających się na starość procesów biologicznych (soma) i psychicznych (psyche) oraz zmian w sferze społecznych zachowań (ethos, polis) ma charakter dynamiczny i synergiczny. Dynamiczny, gdyż zmienia się w czasie. Synergiczny, gdyż te różne procesy wpływają na siebie wzajemnie, przyspieszając lub spowalniając proces starzenia się jednostki"19. Stąd konieczne jest rozpatrywanie wieku człowieka w kategoriach wieku: biologicznego, sprawnościowego, demograficznego, psychicznego, społecznego, ekonomicznego i socjalnego.

Człowiek na swoją starość „pracuje” całe życie. Życie jednak często jest nieprzewidywalne. Nie zawsze osoby, które dbały o zapewnienie sobie dobrej starości, mogą w pełni z niej korzystać i cieszyć się nią. Ważnym elementem w dochodzeniu do wieku podeszłego jest zdrowie, które najczęściej determinuje wybory życiowe. To istotna wartość. Niezależnie od sytuacji z humanitarnego punktu widzenia należy zatroszczyć się o każdego człowieka i pomóc mu godnie przeżyć ostatni etap życia ${ }^{20}$. Trzeba pamiętać, że na naturalnie zachodzący proces starzenia się i na stan zdrowia człowieka wpływają takie czynniki, jak: dziedziczność, a w związku z tym ryzyko wystąpienia pewnych zachorowań, własne zachowania, nawyki, sytuacja materialna, bieżące monitorowanie swojego stanu zdrowia, zachowanie w trakcie leczenia (przede wszystkim stosowanie się do zaleceń lekarza, regularne przyjmowanie leków, na co duży wpływ ma sytuacja materialna pacjenta) ${ }^{21}$.

Wiek i zdrowie są ze sobą powiązane. Zgodność wieku metrykalnego z wiekiem czynnościowym świadczy o prawidłowej, fizjologicznej starości. Natomiast starszy wiek czynnościowy od wieku metrykalnego jest wyznacznikiem starości przedwczesnej - patologicznej. Starość ta w nierozerwalny sposób wiąże się z chorobami, które sprzyjają rozchwianiu równowagi organizmu, co skutkuje upośledzeniem sprawności człowieka oraz zaburzeniami w jego funkcjonowaniu i przystosowaniu².

Niezwykle trudne jest odróżnienie zmian chorobowych od zmian będących konsekwencją fizjologicznego starzenia. Wielochorobowość (multimorbidity), czyli polipatologia, współwystępowanie kilku jednostek chorobowych, jest kolejną przyczyną trudności diagnostycznych u osób w podeszłym wieku. Jest, z jednej strony, konsekwencją starzenia się, a z drugiej - wynikiem rozwoju medycyny i większej skuteczności leczenia chorób przewlekłych. Szacuje się, że u osób po 60. roku życia występują prawie cztery jednostki chorobowe, spośród których najczęstsze są choroby układu krążenia, nowotwory, schorzenia układu oddechowego i narządu ruchu (układu kostno-stawowego, choroba zwyrodnieniowa stawów) ${ }^{23}$. Występowanie polipatologii wiąże się

19 B. Szatur-Jaworska, P. Błędowski, M. Dzięgielewska, Podstawy gerontologii społecznej, Oficyna Wydawnicza ASPRA-JR, Warszawa 2006, s. 45.

20 W. Walkowska, Starzenie się społeczeństw - problem demograficzny czy wyzwanie wspótczesności?, EPALE, 2017, https://ec.europa.eu/epale/pl/blog/starzenie-sie-spoleczenstw-problem-demograficzny-czy-wyzwanie-wspolczesnosci [dostęp: 2 czerwca 2020 r.].

21 R. Suszko, Stan zdrowia oraz potrzeby zdrowotne i opiekuńcze ludzi starych, „Studia BAS” 2012, nr 2(30), s. 30.

22 M. Pieprzyk, P. Pieprzyk, Osoby starsze w systemie ochrony zdrowia, „Ruch Prawniczy, Ekonomiczny i Socjologiczny" 2012, z. 3, s. 177-178, https://doi.org/10.14746/rpeis.2012.74.3.11.

23 Zob. Główny Urząd Statystyczny, Informacja o sytuacji osób starszych na podstawie badań Głównego Urzędu Statystycznego, Warszawa 2018, s. 11-12; Główny Urząd Statystyczny, Sytuacja osób starszych w Polsce w 2018 r., „Analizy statystyczne", Warszawa-Białystok 2020, s. 23-24. 
ze wzrostem liczby zgonów, niesprawności czy zdarzeń niepożądanych. Jej konsekwencją jest częstsze korzystanie z opieki medycznej, instytucjonalizacja i obniżenie jakości życia. I właśnie w takim przypadku można zastosować innowacyjne rozwiązania techniczne. Gerontechnologia wychodzi naprzeciw tym wyzwaniom.

\section{Gerontechnologia - wyjaśnienie pojęcia}

Początki gerontechnologii jako odrębnej dyscypliny badań sięgają lat 90. XX w. Narodziła się zatem niedawno jako odpowiedź na dwa megatrendy, które nie tylko nie zanikły, ale wręcz nasilają się i według prognoz również w przyszłości będą intensywnie oddziaływać na procesy zachodzące w społeczeństwie i w gospodarce. Pierwszy to starzenie się społeczeństw, drugi to szybki rozwój techniki, nowych technologii, zwłaszcza dotyczących komunikacji. To po 1990 r. wprowadzono do użytkowania takie - dobrze znane dzisiaj - produkty i usługi, jak: internet, poczta elektroniczna (e-mail), wyszukiwarki internetowe, telefon komórkowy, GPS (Global Positioning System) i inne narzędzia nawigacyjne, cyfrowe aparaty fotograficzne, gry elektroniczne, roboty czy rozmaite produkty, które znacząco zaczęły ułatwiać prace domowe, wpłynęły na styl i komfort życia oraz na sposób komunikowania się ludzi. Nie tylko zmieniły stosunki społeczne, lecz także oddziałały na zdrowie fizyczne i psychiczne ${ }^{24}$. Termin "gerontechnologia”, wywodzący się z angielskiego - gerontechnology, sugeruje, że ta dyscyplina łączy w sobie dorobek właściwy w szczególności dwóm naukom: gerontologii (gerontology) oraz technologii, a dokładnie trzymając się wcześniej zaprezentowanych uwag terminologicznych - techniki (technology) ${ }^{25}$. W Polsce jednak przyjęło się tłumaczenie: gerontechnologia (nie gerontechnika).

Za autora tego pojęcia uznawany jest Jan A.M. Graafmans, holenderski badacz inżynierii mechanicznej, ergonomiki i technologii zdrowia. Jego współpracownik Herman Bouma dokonał doprecyzowania terminu. Definiuje on „gerontechnologię jako «naukę o technologii i starzeniu się celem poprawy życia codziennego ludzi starych». Istotne jest tu interdyscyplinarne podejście, zgodne z koncepcją zrównoważonego rozwoju, oraz łączenie badań z projektowaniem, produkcją i marketingiem"26.

Warto po krótce przybliżyć pierwszy człon terminu "gerontechnologia". Słowo "gerontologia" wprowadził w 1903 r. Ilia Miecznikow, laureat Nagrody Nobla z zakresu medycyny, jako pojęcie obejmujące rozmaite dziedziny wiedzy zajmujące się starzeniem się i starością. W wersji współczesnej gerontologia ma charakter inter-i multidyscyplinarny, czerpie bowiem z dorobku innych nauk (medycznych, filozoficznych, pedagogicznych, wreszcie - ekonomicznych i infor-

24 J.E.M.H. Bronswijk et al., Defining Gerontechnology for R\&D Purposes, University of South Florida, "Rehabilitation and Mental Health Counseling Faculty Publications" 2009, t. 8, nr 1, s. 4, http://scholarcommons.usf. edu/mhs_facpub/31 [dostęp: 1 października 2020 r.].

25 J.L.H. Birkland, Gerontechnology. Understanding Older Adult Information and Communication Technology Use, Emerald Publishing, United Kingdom-North America-Japan-India-Malaysia-China 2019, s. 6, https://library.oapen.org/bitstream/handle/20.500.12657/24835/1005266.pdf?sequence=1\&isAllowed=y [dostęp: 2 czerwca 2020 r.].

26 A. Wieczorek, Wybrane inżynierskie środki i sposoby poprawy jakości życia osób starszych [w:] Jakość i Bezpieczeństwo, red. M. Molenda, P. Hąbek, „Systemy Wspomagania w Inżynierii Produkcji” 2015, z. 3(12), s. 157. 
matycznych) i konstruuje własną teorię o charakterze aplikacyjnym. W ramach gerontologii wyodrębniono: gerontologię eksperymentalną, medyczną i społeczną. Gerontologia eksperymentalna obejmuje zakres badań dotyczący biologii i fizjologii starzenia się. Gerontologię medyczną tworzą: geriatria (nazywana też medycyną starości), psychogeriatria i geratohigie$n a^{27}$. W społecznym i humanistycznym wymiarze gerontologia rozważa warunki i poziom życia osób starszych: styl wypoczynku, formy rekreacji, organizację wolnego czasu oraz problemy psychologiczne i społeczne (adaptacyjne, normalizacyjne itp.) ${ }^{28}$.

To właśnie gerontologia zajmuje się problematyką jakości życia tej grupy osób. Koncepcja jakości życia jest złożona, dlatego aby zdefiniować jej składowe, należy uwzględnić dobrostan fizyczny, materialny, społeczny, emocjonalny oraz zadowolenie z własnej produktywności. Model jakości życia Centrum Promocji Zdrowia Uniwersytetu w Toronto zakłada trzy kluczowe sfery jakości życia:

- istnieć (psychicznie, fizycznie, duchowo),

- przynależeć (fizycznie, społecznie, socjalnie),

- stawać się (w rozwoju, wypoczynku, działaniu) ${ }^{29}$.

W tych wszystkich sferach może być pomocna nowoczesna technika i technologia. Opracowanie rozwiązań technicznych wspomagających funkcjonowanie osób starszych wymaga rozpoznania wiedzy pochodzącej z takich dziedzin, jak: antropotechnika (w zakresie relacji: człowiek-komputer), psychologia poznawcza, neurobiologia, sztuczna inteligencja, a także inżynieria: informatyczna, elektryczna oraz komunikacji. Głównymi obszarami, z jakimi przychodzi zmierzyć się gerontechnologii, są:

- poznawczo inspirowana informatyka a technologie wspomagające i urządzenia,

- poznawczo inspirowana informatyka a technologie towarzyszące i urządzenia,

- poznawczo inspirowana informatyka a detekcja wypadków domowych,

- emocje (panowanie nad nimi), rozpoznanie i regulacja nastroju,

- spersonalizowana adaptacja otoczenia,

- społeczne/pielęgnacyjne roboty poznawcze i agenci,

- poznawczo inspirowana informatyka a technologie gwarantujące rozrywkę osobom dorosłym,

- poznawczo inspirowana informatyka a fitness i sporty dla seniorów,

- inteligentne telezdrowie, telemedycyna i usługi komunikacyjne,

- sieci społeczne dla osób starszych,

- kształcenie ustawiczne dla zdrowia psychicznego ${ }^{30}$.

Współczesne społeczeństwa, określane mianem społeczeństw informacyjnych, „znajdują się na takim etapie rozwoju technologiczno-organizacyjnego, że osiągnięty poziom zaawan-

27 A. Polak et al., Poznawczy i praktyczny wymiar gerontologii - interdyscyplinarnej nauki o starzeniu się i starości, "Gerontologia Polska" 2007, t. 15, nr 3 s. 52.

28 R.J. Kijak, Z. Szarota, op. cit., s. 5.

29 A. Lada, Jakość życia seniorów, „Annales Universitatis Mariae Curie-Skłodowska. Sectio J. Paedagogia-Psychologia" 2018, t. 31, nr 2, s. 332-333, http://dx.doi.org/10.17951/j.2018.31.2.331-345.

30 A. Wieczorek, Gerontechnologia w rozwiqzywaniu problemów osób starszych [w:] Inżynieria Systemów Technicznych, red. E. Milewska, „Systemy Wspomagania w Inżynierii Produkcji” 2016, z. 2(14), s. 358-359. 
sowania technologii informacyjno-telekomunikacyjnych stwarza warunki techniczne, ekonomiczne, edukacyjne i inne do powszechnego wykorzystania informacji w produkcji wyrobów i świadczenia usług"31. Rozwój nowoczesnych technologii w naturalny sposób wpływa np. na zmiany w systemach ochrony zdrowia i opieki społecznej ${ }^{32}$. W kolejnej części opracowania zostanie scharakteryzowanych kilka wybranych przykładów takich udogodnień i rozwiązań gerontechnologicznych.

\section{Technologia i technika dla lepszej jakości życia osób starszych - wybrane przykłady}

Naturalne skutki wynikające ze starzenia się fizycznego i psychicznego, o czym wspomniano, stały się impulsem do prac nad innowacjami - produktami i usługami, które mogłyby poprawić jakość życia osób starszych. Rozwój techniczny, a zwłaszcza technologiczny, powoduje, że dobra - jeszcze niedawno dostępne dla niewielu - trafiają do większego grona osób. Dzieje się tak przede wszystkim za sprawą obniżenia kosztu, lecz także „dopracowania” - przez co dobra te są łatwiejsze w obsłudze czy choćby z racji mniejszego, kompaktowego rozmiaru bądź udoskonalonego kształtu są łatwiejsze w przenoszeniu i użytkowaniu. Na przykład aparaty słuchowe jeszcze w XX w. były często bardzo nieporęczne. Dziś są to urządzenia na tyle zminiaturyzowane, że umożliwiają funkcjonowanie niemal nieodbiegające od normalności.

Doskonałą ilustracją opisywanego tematu jest alternatywna forma opieki dla osób starszych - teleopieka (telecare). Telecare Services Association (TSA - jedna z największych i najbardziej rozwiniętych organizacji w Wielkiej Brytanii specjalizujących się w teleopiece) definiuje tę formę opieki jako wsparcie udzielane na odległość z wykorzystaniem ICT, które jest świadczone w sposób ciągły, automatyczny, z możliwością zdalnej kontroli, umożliwiające bieżące, bezpieczne funkcjonowanie osobom starszym, niepełnosprawnym czy niesamodzielnym w ich własnych domach przy minimalizacji zagrożeń dla ich zdrowia i życia ${ }^{33}$. Obecny rosnący poziom dostępności infrastruktury ICT (GPS, smartfony, tablety, internet) oraz coraz niższa cena zarówno samych urządzeń, jak i dostępności do infrastruktury, a także coraz wyższy poziom wiedzy w zakresie ich użytkowania stanowią niezbędną masę krytyczną pozwalającą sądzić, że efektywne korzystanie z portali internetowych, telekonsultacji, e-learningu, zdalnego monitoringu funkcji życiowych oraz innych usług telemedycyny jest możliwe ${ }^{34}$.

Produktem coraz częściej stosowanym w ramach zdalnej kontroli zdrowia jest opaska telemedyczna SOS (nazywana też ratunkową) ${ }^{35}$. Jest to niewielkie urządzenie, wzorowane na

31 Zob. Główny Urząd Statystyczny, Społeczeństwo informacyjne w Polsce. Wyniki badań statystycznych lat 20152019, Warszawa 2019

32 J. Kilian et al., Teleopieka jako skuteczne rozwiqzzanie w obliczu zjawiska wzrastajqcego zapotrzebowania na opieke długoterminową, „Niepełnosprawność - zagadnienia, problemy, rozwiązania” 2018, nr 1(26), s. 147-148.

33 Ibidem, s. 147.

34 T. Osman et al., Kierunek rozwoju teleopieki w Polsce na tle doświadczeń Wielkiej Brytanii, Norwegii i Niemiec wstęp do dyskusji, ",Gerontologia Polska” 2018, t. 26, nr 4, s. 300.

35 Są to m.in. opaski SiDLY Care polskiej innowacyjnej spółki specjalizującej się w systemach teleopieki. 
opaskach aktywności fizycznej, przypominające zegarek (zresztą, co warto dodać, zegarki - tzw. smartwatche - także posiadają podobne funkcje ${ }^{36}$ ), które łączy w sobie funkcje kilku urządzeń medycznych. Zaprojektowano ją z myślą np. o osobach starszych, które mieszkają samotnie lub wymagają stałego monitorowania i ciągłej opieki. Opaska telemedyczna została stworzona w celu poprawy poczucia bezpieczeństwa osób starszych i niepełnosprawnych. Jej obsługa jest łatwa i w pełni dostosowana do możliwości każdego seniora. Urządzenia są lekkie, wodoszczelne i nie przeszkadzają w codziennym funkcjonowaniu. Nie ma także konieczności zdejmowania ich do kąpieli ani do snu, dlatego można mieć je stale przy sobie bez obawy, że się o nich zapomni. Opaski są wyposażone w akumulatory, które należy ładować średnio co kilka dni. Można już nabyć:

- opaski przypominające o konieczności przyjęcia leków,

- opaski dokonujące cyklicznego pomiaru tętna, temperatury ciała, ciśnienia tętniczego krwi, liczby wykonanych kroków,

- opaski posiadające nadajnik GPS, pokazujące lokalizację danej osoby,

- opaski z detektorem upadku,

- opaski umożliwiające wezwanie pomocy przez naciśnięcie guzika SOS,

- opaski telemedyczne umożliwiające telemonitoring i połączenia głosowe.

Kolejną innowacją w służbie osobom starszym jest tzw. inteligentny dom (smart home) ${ }^{37}$. Chroni on np. przed niebezpieczeństwem zapomnienia o wyłączeniu mediów, wody czy zażyciu leków. Umożliwia sterowanie urządzeniami gospodarstwa domowego za pomocą gestu, głosu bądź ustalonych wcześniej harmonogramów. Taki dom sprawdza, czy senior jest aktywny, czy wyszedł z domu w ciągu ostatnich 24 godzin lub czy nie doszło do wypadku (upadku). Całość zdalnie nadzoruje profesjonalnie przeszkolony konsultant, który - gdy zauważy coś niepokojącego - dzwoni do opiekuna.

Automatyzacja i robotyzacja są tymi czynnikami, które mogą poprawić jakość życia osobom starszym i przewlekle chorym. Rozwiązaniem, które to umożliwia, jest wykorzystanie robotów terapeutycznych. Badania nad robotami uczestniczącymi w opiece nad osobami starszymi koncentrują się na opracowaniu robotów wspomagających, które mogą być robotami asystującymi przy rehabilitacji osób starszych lub robotami społecznymi.

Pierwszy typ badań dotyczy technologii wspomagających, które nie są nastawione na zapewnienie komunikatywności robotów z osobami starszymi i nie są traktowane jako podmioty społeczne (m.in. inteligentne wózki inwalidzkie, protezy kończyn i zewnętrzne szkielety). Przykładem technologii wspomagającej jest też system ATRS (Automated Transport and Retrieval System), stworzony przez inżynierów z Uniwersytetów Lehigh i Carnegie Mellon. Ułatwia on użytkownikom wózków inwalidzkich wsiadanie do samochodów i wysiadanie z nich, otwieranie

36 Smartwatche są z wyglądu podobne do tradycyjnych zegarków. Smartwatche wyróżnia jednak to, że mają dotykowy ekran LCD oraz łącze Bluetooth, dzięki czemu komunikują się ze smartfonem. Nowoczesne funkcje pozwalają na wyświetlanie wiadomości i powiadomień z urządzeń mobilnych, odbieranie rozmów czy pomiar podstawowych parametrów życiowych (np. Apple Watch, Calmean Senior Watch lub Beurer).

37 H.M. Do et al., RiSH: A robot-integrated smart home for elderly care, „Robotics and Autonomous Systems" 2018, t. 101, s. 74-92, https://doi.org/10.1016/j.robot.2017.12.008. 
i blokowanie drzwi oraz kierowanie pojazdem. System ATRS składa się z trzech komponentów: specjalnego siedzenia, które można poszerzyć w celu ułatwienia przejścia z wózka inwalidzkiego na fotel, platformy podnoszącej oraz inteligentnego systemu wózka inwalidzkiego ${ }^{38}$.

Drugi obszar badań koncentruje się na robotyce społecznej i dotyczy systemów, które mogą być postrzegane jako podmioty społeczne, komunikujące się z użytkownikiem. Prace nad robotami społecznymi w opiece nad osobami starszymi obejmują kilka rodzajów robotów: roboty typu „usługi”, roboty przypominające zwierzęta lub roboty humanoidalne (przypominające ludzi) ${ }^{39}$.

Przykładem w tym zakresie może być finansowany przez Unię Europejską oraz Ministerstwo Spraw Zagranicznych i Komunikacji Japonii projekt CARESSES (Culture Aware Robots and Environmental Sensor Systems for Elderly Support $)^{40}$. Ma on na celu stworzenie pierwszych na świecie robotów uwzględniających różnice kulturowe, mających służyć opiece nad osobami starszymi. Przełomowa koncepcja polega na zaprojektowaniu robotów, które dostosowują sposób, w jaki się zachowują i mówią, do kultury i nawyków osoby starszej, której mają pomagać. Naukowcy testowali już pierwsze roboty CARESSES w domach opieki w Wielkiej Brytanii i w Japonii. Celem było sprawdzenie, czy ludzie czują się bardziej komfortowo z robotami, które uwzględniają różnice kulturowe podczas komunikowania się z nimi. Naukowcy sprawdzają również, czy tego rodzaju roboty faktycznie poprawiają jakość życia osób starszych.

Dostępny natomiast komercyjnie jest już inny robot: ElliQ ${ }^{41}$. Amerykańska spółka Intuition Robotics przez prawie rok robiła testy beta w domach ludzi w wieku 62-97 lat zamieszkałych w rejonie Zatoki San Francisco. Pozytywny efekt badań doprowadził do wprowadzenia robota do powszechnego użytku.

Warto podkreślić, że wyniki licznych badań (w tym prowadzonych przez naukowców z Uniwersytetu Medycznego w Poznaniu w ramach projektu ENRICHME - Enabling Robot and assisted living environment for Independent Care and Health Monitoring of the Elderly - Analiza potrzeb osób starszych w kontekście możliwości zastosowania robotów pomagających im funkcjonować samodzielnie w domu) dotyczących wykorzystywania robotów w codziennych czynnościach przez osoby starsze potwierdzają, że roboty są akceptowane i pozytywnie oceniane przez użytkowników w podeszłym wieku. Jak czytamy we wnioskach: „znamienne jest, że osoby starsze są bardziej otwarte na użycie technologii, niż postrzegają to osoby młodsze". Dodatkowo jest ważne, że „respondenci twierdzili, że w przyszłości osoby starsze będą lepiej przygotowane

38 Też o pionierskim, zmodyfikowanym SmartATRS zob. P. Whittington, H. Dogan, K. Phalp, Evaluating the Usability of an Automated Transport and Retrieval System [w:] Proceedings of the 5th International Conference on Pervasive and Embedded Computing and Communication Systems, t. 1, PECCS, Angers, Loire Valley, France 2015, https://doi.org/10.5220/0005205000590066.

39 A. Wieczorek, Gerontechnologia..., s. 364; P. Stylec-Szromek, Jakość życia w procesie starzenia się a rozwój techniki medycznej, „Zeszyty Naukowe Politechniki Śląskiej” 2017, seria „Organizacja i Zarządzanie”, z. 119, s. 364, https://doi.org/10.29119/1641-3466.2017.112.30; S. Tobis, Robot społeczny - definicja i zastosowanie, "Geriatria" 2018, nr 12, s. 247-250, https://www.akademiamedycyny.pl/wp-content/uploads/2019/04/Tobis_2.pdf [dostęp: 2 czerwca 2020 r.].

40 Strona projektu CARESSES: http://caressesrobot.org/en/ [dostęp: 2 czerwca 2020 r.].

41 https://elliq.com/ [dostęp: 2 czerwca 2020 r.]. 
na używanie technologii niż obecnie, ale już dzisiaj niektóre osoby starsze bardzo sprawnie obsługują smartfony i komputery, a więc dla nich obsługa robota nie będzie wcale trudna"42.

Wśród produktów, które wpisują się w poruszaną tematykę, należy wspomnieć na koniec o tych, które są finansowane środkami europejskimi w programie wspierania innowacji i pomysłów w tym obszarze. Active and Assisted Living Programme (AAL) to program badawczo-rozwojowy, współfinansowany przez Komisję Europejską w ramach programu Horyzont 2020, który promuje projekty wykorzystujące technologie informacyjno-komunikacyjne (ICT), by poprawić jakość życia ludzi starszych. Głównym celem programu jest stymulacja generowania innowacyjnych produktów, usług i systemów opartych na ICT. W ramach realizowanego programu raz w roku ogłaszane są konkursy. Każdy z nich koncentruje się na innym zagadnieniu. Od 2008 r. sfinansowano 240 projektów ${ }^{43}$. Dzięki temu powstał np. system gier do rehabilitacji (Rehabilitation Gaming System - RGS) ${ }^{44}$ czy projekt CapMouse, który doprowadził do opracowania LipIt - technologii głośnomówiącej, która umożliwia osobom starszym i niepełnosprawnym korzystanie z komputerów za pomocą ruchów warg. Po uzyskaniu patentów amerykańskich i unijnych zespół projektowy stara się teraz wprowadzić tę technologię na nowo powstający rynek rzeczywistości rozszerzonej ${ }^{45}$.

\section{Zakończenie}

Starsi ludzie coraz chętniej korzystają z nowych technologii, ponieważ stają się one bardziej dostępne z racji zarówno łatwości obsługi, jak i ceny zakupu. Można też znaleźć więcej informacji na ich temat. Osoby starsze mogą dowiedzieć się o wprowadzanych innowacjach ze szkoleń czy kursów na tzw. uniwersytetach trzeciego wieku lub po prostu od młodszych członków rodziny ${ }^{46}$. Obce słowa: „smartfon”, „e-mail”, „portal”, „internet” czy „chat”, niegdyś w rozumieniu seniorów „zarezerwowane dla młodych”, teraz weszły do słownika wielu osób po 60. roku życia i są normalną częścią ich codzienności ${ }^{47}$. Powodów może być wiele: niektóre z nich są zewnętrzne (np. chęć zaimponowania wnukom), lecz przeważają te wewnętrzne (m.in. chęć nauki i poznawania czegoś nowego $)^{48}$. Wydaje się jednak, że kolejne pokolenia wkraczające w wiek, który jest

42 S. Tobis, J. Suwalski, Opinie osób starszych na temat robota społecznego i jego zastosowania, „Geriatria” 2015, nr 9, s. 267-273, https://www.akademiamedycyny.pl/wp-content/uploads/2016/05/201504_Geriatria_008. pdf [dostęp: 2 czerwca 2020 r.].

43 http://www.aal-europe.eu/ [dostęp: 2 czerwca 2020 r.].

44 http://www.aal-europe.eu/rehabilitation-gaming-systems/ [dostęp: 2 czerwca 2020 r.].

45 http://www.aal-europe.eu/capmouse/ [dostęp: 2 czerwca 2020 r.].

46 Intelektualny rezultat 2. Raport dotyczący międzypokoleniowych i wewnątrzpokoleniowych programów edukacyjnych, poprawiających umiejętności cyfrowe starszych dorosłych, projekt ICTskills4All. Wzmocnienie pozycji starszych dorosłych obywateli w świecie cyfrowym, 2019, https://up.pt/ictskills4all/wp-content/uploads/ sites/297/2019/09/O2_PL.pdf [dostęp: 2 czerwca 2020 r.].

47 Np. strona internetowa z nowinkami technicznymi dedykowana tej grupie: TechnoSenior, https://techno-senior.com/o-nas/ [dostęp: 2 czerwca 2020 r.]. Według danych GUS w Polsce odsetek osób regularnie korzystających z komputera w grupie 65-74 lata wzrósł z 20,1\% w 2015 r. do 30,6\% w 2019 r. Zob. Główny Urząd Statystyczny, Społeczeństwo informacyjne..., s. 146.

48 B. Szmigielska, A. Bąk, A. Jaszczak, Komputer i Internet w życiu e-seniorów - doniesienie z badań jakościowych, „Studia Edukacyjne" 2012, nr 23, s. 349-350. 
postrzegany jako „starszy”, będą jeszcze bardziej poprawiać statystyki dotyczące umiejętności cyfrowych „seniorów”. Postęp w tej dziedzinie jest bowiem szybki, ale człowiek zawsze będzie starał się dążyć do tego, aby mu dorównać.

Podsumowując: przedstawione w opracowaniu wybrane przykłady projektów (także prototypów) i produktów, które już są w powszechnym użyciu, pozwalają pozytywnie odnieść się do tezy, że tego typu technologie służą poprawie jakości życia osób starszych. Skoncentrowano się na innowacjach związanych ze zdrowiem, aktywnością fizyczną i mieszkaniem. Należy jednak pamiętać, że przecież osoby starsze już teraz np. korzystają z bankowości elektronicznej czy robią zakupy przez internet. Wobec prognozowanej globalnej tendencji zmian demograficznych można stwierdzić, że gerontechnologia będzie się dynamicznie rozwijać.

\section{Bibliografia}

Birkland J.L.H., Gerontechnology. Understanding Older Adult Information and Communication Technology Use, Emerald Publishing, United Kingdom-North America-Japan-India-Malaysia-China 2019, https://library. oapen.org/bitstream/handle/20.500.12657/24835/1005266.pdf?sequence=1\&isAllowed=y.

Błędowski P., Szatur-Jaworska B., Szweda-Lewandowska Z., Kubicki P., Raport na temat sytuacji osób starszych w Polsce, Instytut Pracy i Spraw Socjalnych, Warszawa 2012.

Bronswijk J.E.M.H. et al., Defining Gerontechnology for R\&D Purposes, University of South Florida, „Rehabilitation and Mental Health Counseling Faculty Publications" 2009, t. 8, nr 1, http://scholarcommons.usf.edu/ mhs_facpub/31.

Do H.M. et al., RiSH: A robot-integrated smart home for elderly care, „Robotics and Autonomous Systems" 2018, t. 101, https://doi.org/10.1016/j.robot.2017.12.008.

Gee E.M., Population and Politics: Voodoo Demography, Population Aging, and Social Policy [w:] The Overselling of Population Aging: Apocalyptic Demography, Intergenerational Challenges, and Social Policy, red. E.M. Gee, G.M. Gutman, Oxford University Press, Toronto, Ontario 2000.

Główny Urząd Statystyczny, Informacja o sytuacji osób starszych na podstawie badań Głównego Urzędu Statystycznego, Warszawa 2018.

Główny Urząd Statystyczny, Społeczeństwo informacyjne w Polsce. Wyniki badań statystycznych lat 2015-2019, Warszawa 2019.

Główny Urząd Statystyczny, Sytuacja demograficzna osób starszych i konsekwencje starzenia się ludności Polski w świetle prognozy na lata 2014-2050, Warszawa 2014.

Główny Urząd Statystyczny, Sytuacja osób starszych w Polsce w 2018 r., „Analizy statystyczne”, Warszawa-Białystok 2020.

Gomułka S., Teoria innowacji i wzrostu gospodarczego, Centrum Analiz Społeczno-Ekonomicznych, Warszawa 1998. Indywidualne aspekty starzenia się. Między możliwościami a ograniczeniami, red. A. Stogowski, S. Dzięgielewska-Gęsiak, Wyższa Szkoła Nauk Humanistycznych i Dziennikarstwa w Poznaniu, Poznań 2013.

Intelektualny rezultat 2. Raport dotyczący międzypokoleniowych i wewnątrzpokoleniowych programów edukacyjnych, poprawiających umiejętności cyfrowe starszych dorosłych, projekt ICTskills4All. Wzmocnienie pozycji starszych dorosłych obywateli w świecie cyfrowym, 2019, https://up.pt/ictskills4all/wp-content/uploads/ sites/297/2019/09/02_PL.pdf. 
Kilian J. et al., Teleopieka jako skuteczne rozwiqzzanie w obliczu zjawiska wzrastajacego zapotrzebowania na opiekę długoterminowq, „Niepełnosprawność - zagadnienia, problemy, rozwiązania” 2018, nr 1(26).

Lada A., Jakość życia seniorów, „Annales Universitatis Mariae Curie-Skłodowska. Sectio J. Paedagogia-Psychologia" 2018, t. 31, nr 2, http://dx.doi.org/10.17951/j.2018.31.2.331-345.

Łach T., Strach przed postępem - kilka uwag o nurtach antytechnicznych, „Kultura i Wartości” 2012, nr 4, http://kulturaiwartosci.umcs.lublin.pl/wp-content/uploads/2011/11/Tomasz-\%C5\%81ach-Strach-przed-post\%C4\%99pem-kilka-uwag-o-nurtach-antytechnicznych.pdf.

Łucki Z., Proszę... nie mówmy „technologia” na technikę!, https://www.uci.agh.edu.pl/bip/63/11_63.htm.

Makuch M., Polityka społeczna dotycząca starości [w:] K. Zamorska, M. Makuch, Starzenie się społeczeństwa. Wymiar społeczny, gospodarczy i polityczny, Księgarnia Akademicka, Kraków 2018.

Megatrends 2015. Making sense of a world in motion, EY, 2015, https://www.ey.com/Publication/vwLUAssets/ey-megatrends-report-2015/\$FILE/ey-megatrends-report-2015.pdf.

Migała-Warchoł A., Sobolewski M., Innowacyjność gospodarki a poziom życia mieszkańców państw Unii Europejskiej, „Barometr Regionalny" 2017, t. 15, nr 4, http://br.wszia.edu.pl/zeszyty/pdfs/br50_05migala.pdf.

Osman T. et al., Kierunek rozwoju teleopieki w Polsce na tle doświadczeń Wielkiej Brytanii, Norwegii i Niemiec - wstęp do dyskusji, „Gerontologia Polska” 2018, t. 26, nr 4.

Pieprzyk M., Pieprzyk P., Osoby starsze w systemie ochrony zdrowia, „Ruch Prawniczy, Ekonomiczny i Socjologiczny” 2012, z. 3, https://doi.org/10.14746/rpeis.2012.74.3.11.

Polak A. et al., Poznawczy i praktyczny wymiar gerontologii - interdyscyplinarnej nauki o starzeniu się i starości, "Gerontologia Polska" 2007, t. 15, nr 3.

Prandecki K., Rola megatrendów w przewidywaniu przyszłości, „Przyszłość. Świat - Europa - Polska” 2012, nr 2, Komitet Prognoz „Polska 2000 Plus” przy Prezydium PAN, Warszawa.

Sobczak R., Inżynier: wiedza, technika, technologia, „Zeszyty Naukowe Wydziału Elektrotechniki i Automatyki Politechniki Gdańskiej" 2017, t. 52.

Stylec-Szromek P., Jakość życia w procesie starzenia się a rozwój techniki medycznej, „Zeszyty Naukowe Politechniki Śląskiej” 2017, seria „Organizacja i Zarządzanie”, z. 119, https://doi.org/10.29119/1641-3466.2017.112.30.

Suszko R., Stan zdrowia oraz potrzeby zdrowotne i opiekuńcze ludzi starych, „Studia BAS” 2012, nr 2(30).

Szarota Z., Społeczno-demograficzne aspekty starzenia się społeczeństwa [w:] R.J. Kijak, Z. Szarota, Starość. Między diagnoza a działaniem, Centrum Rozwoju Zasobów Ludzkich, Warszawa 2013.

Szatur-Jaworska B., Błędowski P., Dzięgielewska M., Podstawy gerontologii społecznej, Oficyna Wydawnicza ASPRA-JR, Warszawa 2006.

Szmigielska B., Bąk A., Jaszczak A., Komputer i Internet w życiu e-seniorów - doniesienie z badań jakościowych, „Studia Edukacyjne" 2012, nr 23.

Szukalski P., Proces starzenia się ludności - przyczyny, etapy, konsekwencje [w:] Geriatria z elementami gerontologii ogólnej. Podręcznik dla lekarzy i studentów, red. T. Grodzicki, J. Kocemba, A. Skalska, Via Medica, Gdańsk 2006.

Szukalski P., Zagrożenie czy wyzwanie - proces starzenia się ludności, „Polityka Społeczna” 2006, nr 9.

Tobis S., Robot społeczny - definicja i zastosowanie, "Geriatria” 2018, nr 12, https://www.akademiamedycyny.pl/ wp-content/uploads/2019/04/Tobis_2.pdf.

Tobis S., Suwalski J., Opinie osób starszych na temat robota społecznego i jego zastosowania "Geriatria” 2015, nr 9, https://www.akademiamedycyny.pl/wp-content/uploads/2016/05/201504_Geriatria_008.pdf. 
United Nations Development Programme, Human Development Reports, table 2: Human Development Index Trends, 1990-2018, http://hdr.undp.org/en/content/table-2-human-development-index-trends-1990\%E2\%80\%932018.

United Nations, World Population Prospects. The 2015 Revision. Key Findings and Advance Tables, New York 2015, https://population.un.org/wpp/Publications/Files/Key_Findings_WPP_2015.pdf.

Walkowska W., Starzenie się społeczeństw - problem demograficzny czy wyzwanie wspótczesności?, EPALE, 2017, https://ec.europa.eu/epale/pl/blog/starzenie-sie-spoleczenstw-problem-demograficzny-czy-wyzwanie-wspolczesnosci.

What's after what's next? The upside of disruption. Megatrends shaping 2018 and beyond, EY, 2018, https://assets. ey.com/content/dam/ey-sites/ey-com/en_gl/topics/disruption/ey-megatrends-final-onscreen.pdf.

Whittington P., Dogan H., Phalp K., Evaluating the Usability of an Automated Transport and Retrieval System [w:] Proceedings of the 5th International Conference on Pervasive and Embedded Computing and Communication Systems, t. 1, PECCS, Angers, Loire Valley, France 2015 https://doi.org/10.5220/0005205000590066.

Wieczorek A., Gerontechnologia w rozwiqzzywaniu problemów osób starszych [w:] Inżynieria Systemów Technicznych, red. E. Milewska, "Systemy Wspomagania w Inżynierii Produkcji” 2016, z. 2(14).

Wieczorek A., Wybrane inżynierskie środki i sposoby poprawy jakości życia osób starszych [w:] Jakość i Bezpieczeństwo, red. M. Molenda, P. Hąbek, „Systemy Wspomagania w Inżynierii Produkcji” 2015, z. 3(12).

World Health Organization, Ageing and health, https://www.who.int/news-room/fact-sheets/detail/ageing-and-health.

\section{Źródła internetowe}

http://www.aal-europe.eu/.

http://www.aal-europe.eu/capmouse/.

http://www.aal-europe.eu/rehabilitation-gaming-systems/.

http://caressesrobot.org/en/.

https://elliq.com/.

https://techno-senior.com/o-nas/. 